doi: 10.17492/pragati.v3i2.7747

\title{
Comparative Analysis of LIC of India with Private Players
}

\author{
Tanu Dhingra*
}

\begin{abstract}
Before 1999, the insurance sector was characterized by state-run monopoly, with LIC as the only player. On the recommendations of the Malhotra Committee in the year 1999, the insurance sector was opened up for national and international players. Competition started shooting up and insurance business started witnessing a growth in premium as a percentage of GDP (insurance penetration) from 2.3\% p.a. in 2001 to 5.2\% p.a. in 2011. Thus, the need was realised to find out the growth of insurance companies in terms of various indicators pertaining to insurance business and to have a comparative analysis of growth of life insurance companies in India. The objective of this paper is to analyse and comment upon the growth rate of thirteen life insurance companies covered for the study for a period of eight years. It has been found in the study that almost all life insurance companies are witnessing a rising trend in terms of various growth indicators, though the growth rate for different companies is different. The main question is whether LIC has been affected by the competition. We have tried to answer this question through the empirical analysis of performance of individual insurance companies. In terms of most of variables LIC has been at the bottom of the list.
\end{abstract}

Keywords: Life insurance, Growth indicators, Performance of Life Insurers.

\subsection{Introduction}

Since the year 1999 when financial liberalisation of insurance sector was initiated on the recommendations of Malhotra Committee, there has been a considerable transformation of the market structure of the Indian insurance industry. The Government of India allowed private sector and 26\% Foreign Direct Investment in the insurance business. Joint ventures of Indian insurers with foreign counterparts started flourishing. By September 2013, there were as many as 24 life insurance companies operating in India.

*Assistant Professor, Department of Commerce, Mata Sundri College for Women, University of Delhi (email: dhingra.tannu@gmail.com) 
With the coming up of the private players and joint ventures of Indian companies with the foreign insurance companies, Indian life insurance market has acquired position in the top five countries in terms of number of policies in force. The Indian insurance business has been growing rapidly and the insurance penetration ratio (premium as a percentage of GDP) has gone up from 2.3\% in 2001 to $5.2 \%$ in 2011. There has also been a rapid growth of multiple channels of distribution.

While the insurance industry has come a long way over the past decade, the players in the industry face a big challenge of profitability. Private life insurers have accumulated huge losses. The gestation period for having a successful insurance business or say, turnaround of business takes 10-15 years.

Despite these realities, the life insurers are showing considerable growth in terms of new policies issued, first year premium, total life insurance premium, and capturing of increased market share in terms of total premium. The objective of this paper is to have a comparative analysis of the growth of the life insurance companies under study in terms of various variables in insurance. A sample size of 13 companies has been selected. The justification of the sample size is that these thirteen companies, together garnered $99.9 \%$ market share in terms of total premium in the year 2005-2006, and represented $97 \%$ of the market share in the year 2012-2013. Hence, the sample size is justifies in making comparative analysis of the growth of the companies. Profiles of companies have been prepared so as to ascertain the progress made by them over the period of 8 years under study starting from 2005-06 to 2012-2013.

The paper is divided into the following sections. Section 2 provides a brief review of literature, which focuses on analysing life insurance companies operating in India on the basis of certain financial or insurance related variables. Section 3 shows a list of life insurance companies chosen for the study; Section 4 focuses on methodology of the paper; Section 5 defines the growth indicators chosen in the paper; Section 6 does a comparative analysis of companies in terms of chosen indicators; and Section 7 provides summary and conclusions.

\subsection{Review of Literature}

A reasonable amount of literature is referred to analyse life insurance companies and make a comparison amongst them. More recently, Agarwal (2014) explains the concept of insurance and life insurance and performance of life insurers in terms of various indicators. Tanu and Goswami (2014) analyse insurance penetration and density in India. The authors also analyse the growth of real premium. 
Ashturkar (2014) measures and compares the performance of life insurance companies from the point of view of claims paid and unpaid for the year 2012-2013 and concludes that the claim settlement process of LIC is the fastest among all the private life insurers. Nagaraja (2014) compares the performance of life and non-life insurance companies in terms of their premium income, market share, new policies issued and claims settlement. The author also comments on low insurance penetration and density in percentage terms in India. Bawa and Chattha (2013) analyse the financial performance of 18 Indian life insurance companies and examine the impact of liquidity, solvency, capital, size, leverage on the profitability of these companies. The paper concludes that LIC was the best in terms of its performance of leverage in comparison to its competitors. Neelaveni, V. (2012) analyse the financial performance of five life insurance companies namely, LIC, ICICI Prudential, Bajaj Alliance, Birla SunLife, and ING Vyasa. The paper highlights the computation and comparative analysis of compounded annual growth rate of 15 financial variables like, fixed assets, share capital, current assets, cash and bank balance.

Garg and Verma (2010) study the nature, pattern, and process of marketing mix programmes followed by life insurance companies in India. Sinha (2009) estimate the cost efficiency of life insurance companies operating in India. The results suggest a rising trend in the cost efficiency in the initial years of study that is, from 2002 till 2005 and observe a downfall in it in the later years. Dhingra (2016) elaborated upon the various elements of market micro structure of life insurance industry in India. The paper analyses the growth trends of variables peculiar to life insurance industry. It concludes that Indian life insurance industry has been on the growth path as all variables studied showed a consistent rise.

\subsection{List of Life Insurance Companies chosen for the Study}

The list of life insurance companies chosen for study is given in Table 1 below. The objective is to have a bird's eye view of the status of life insurers operating in India. Since we are analysing 13 life insurance companies operating in India, the details regarding names of the insurers, the date of registration, their foreign alliances and their year of operation is specified only for these companies.

\subsection{Methodology}

Keeping in view the objective of the paper to analyse the growth of life insurance companies in terms of various indicators of growth, the research design incorporates 
various steps for developing a set of appropriate methodology. The paper has incorporated "Growth Analysis" as its methodology for empirical analysis.

Table 1: Life Insurance Companies

\begin{tabular}{|c|c|c|c|c|}
\hline $\begin{array}{l}\text { S. } \\
\text { No. }\end{array}$ & Insurers & Foreign Partners & $\begin{array}{c}\text { Date of } \\
\text { Registration }\end{array}$ & $\begin{array}{l}\text { Year of } \\
\text { Commenc } \\
\text { ement }\end{array}$ \\
\hline \multicolumn{5}{|c|}{ Private Sector } \\
\hline 1. & $\begin{array}{l}\text { Aviva Life Insurance } \\
\text { Company Ltd. }\end{array}$ & $\begin{array}{l}\text { Aviva International } \\
\text { Holdings Ltd. UK }\end{array}$ & 14.05 .2002 & $2002-2003$ \\
\hline 2. & $\begin{array}{l}\text { Bajaj Allianz Life } \\
\text { Insurance Company Ltd. }\end{array}$ & Allianz, SE Germany & 03.08.2001 & 2001-2002 \\
\hline 3. & $\begin{array}{l}\text { Birla Sun Life Insurance } \\
\text { Company Ltd. }\end{array}$ & $\begin{array}{l}\text { Sun Life Financial Insurance } \\
\text { Investment Inc, Canada }\end{array}$ & 31.01 .2001 & $2000-2001$ \\
\hline 4. & $\begin{array}{l}\text { HDFC Standard Life } \\
\text { Insurance Company Ltd. }\end{array}$ & $\begin{array}{l}\text { Standard Life (Mauritius } \\
\text { Holdings) 2006, Ltd. UK }\end{array}$ & 23.10 .2000 & 2000-2001 \\
\hline 5. & $\begin{array}{l}\text { ICICI Prudential Life } \\
\text { Insurance Company Ltd. }\end{array}$ & $\begin{array}{l}\text { Prudential Corporation } \\
\text { Holdings Ltd. UK }\end{array}$ & 24.11 .2000 & $2000-2001$ \\
\hline 6. & $\begin{array}{l}\text { ING Vysya Life } \\
\text { Insurance Company Ltd }\end{array}$ & ---- & 02.08 .2001 & 2001-2002 \\
\hline 7. & $\begin{array}{l}\text { Kotak Mahindra OM Life } \\
\text { Insurance Company Ltd }\end{array}$ & $\begin{array}{l}\text { Old Mutual Plc, South } \\
\text { Africa }\end{array}$ & 10.01 .2001 & 2001-2002 \\
\hline 8. & $\begin{array}{l}\text { MaxLife Insurance } \\
\text { Company Ltd. }\end{array}$ & $\begin{array}{l}\text { Mitsui Sumitomo Insurance } \\
\text { Company Ltd. Japan }\end{array}$ & 15.11 .2000 & 2000-2001 \\
\hline 9. & $\begin{array}{l}\text { PNB Metlife India } \\
\text { Insurance Company Ltd }\end{array}$ & $\begin{array}{l}\text { Metlife International } \\
\text { Holdings Inc, USA }\end{array}$ & 06.08 .2001 & 2001-2002 \\
\hline 10. & $\begin{array}{l}\text { Reliance Life Insurance } \\
\text { Company Ltd. }\end{array}$ & $\begin{array}{l}\text { Nippon Life Insurance } \\
\text { Company Ltd. Japan }\end{array}$ & 03.01 .2002 & 2001-2002 \\
\hline 11. & $\begin{array}{l}\text { SBI Life Insurance } \\
\text { Company Ltd. }\end{array}$ & BNP Paribas Cardif, France & 29.03.2001 & 2001-2002 \\
\hline 12. & $\begin{array}{l}\text { TATA AIA Life } \\
\text { Insurance Company Ltd. }\end{array}$ & $\begin{array}{l}\text { American International } \\
\text { Assurance Company } \\
\text { (Bermuda Ltd.) }\end{array}$ & 12.02 .2001 & 2001-2002 \\
\hline \multicolumn{5}{|c|}{ Public Sector } \\
\hline 1. & $\begin{array}{l}\text { Life Insurance } \\
\text { Corporation of India }\end{array}$ & & 01.09 .1956 & $1956-57$ \\
\hline
\end{tabular}

Source: IRDA Handbook, 2012-2013 
84 | PRAGATI: Journal of Indian Economy, Volume 3, Issue 2

\subsection{Growth Analysis}

The general trends to study the overall growth rates are discussed with the help of semi-log equations for various indicators of growth. The purpose behind such an analysis is to show the annual growth rate. We have regressed the log of each variable with respect to time. Therefore, regression equation can be written in exponential form as follows:

$$
\mathrm{Y}=e^{\alpha+\beta t}
$$

Taking log of both sides and adding an error term;

$\log Y=\alpha+\beta t+\mu t$

where

$\log \mathrm{Y}=$ natural $\log$ of variable $\mathrm{Y}$

$\alpha \quad=$ intercept term

$\beta=$ slope of regression equation, which basically tells us about growth rate

$\mathrm{t} \quad=$ Time $(2005-2013)$

$\mu \quad=$ Error term

Hence, to compute the exponential growth of the life insurance companies during the selected period from 2005-06 to 2012-2013, semi-log regression model is used for the analysis. It is also called log-lin model as in this model, only the regressand (dependent variable) appears in the logarithmic form.

The regression is carried out for some of the important indicators of growth for all thirteen companies under study. The following indicators of growth have been selected and semi-log regression analysis is done to compute the instantaneous growth rates:

i. New policies issued;

ii. First year premium;

iii. Sum assured;

iv. Net benefit paid;

v. Total life insurance premium;

vi. Market share

\subsection{Construction of Growth Indicators}

The growth indicators are defined and constructed as follows:

\subsection{New policies issued}

New policies issued refer to additions to total policies during the year of individual business. In other words, it refers to the new life insurance policies issued by the life insurers to the customers (insured). Each company issues new policies every year. The progress made by the company in terms of growth of new policies issued indicates the 
presence and popularity. It also indicates the growth of the business since growth depends upon generation of revenue each year from the core business which is underwriting of new policies.

\subsection{First year premium}

As per IRDA Handbook 2012-2013, the term first year premium refers to first year premium including single premium. It does not include renewal premium. In other words, first year premium refers to premium earned by life insurers on the new policies issued by them in current year. Such premium includes premium which is received once in life time of the policy. It does not include premium earned by the companies on the policies which are issued in previous years. It represents income pertaining to the current year from the core business (insurance). The growth rate of first year premium indicates the growth rate of business in terms of its earnings every year from the current year's business.

\subsection{Sum assured}

Sum assured represents the scale of operation of the life insurer. It represents the total amount for which life insurance is undertaken by the insured. It is that sum of money which would be payable to insured at the time of expiry of the insurance policy. The higher the sum assured, the higher the scale of operation it represents of the life insurer. The growth rate of the sum assured would depict the growth of the scale at which business of life insurer is operating.

\subsection{Net benefit paid}

Net benefit paid refers to the insurance claims paid by the life insurers to the insured at the time of death or maturity or paid during the life of the insurance contract in the form of various riders and other benefits such as bonus etc. Net benefit paid includes insurance claims by death, by maturity, pension payments, and other benefits.

\subsection{Total life insurance premium}

Total life insurance premium refers to the life insurance premium earned by life insurers every year on the total policies issued by them, whether in the previous years or in the current year. The growth rate of total life insurance premium is an important indicator of the growth of the business. It is one Figure which depicts the state of affairs of the business of insurer. It is the determinant of market share of the life insurance company in the industry.

\subsection{Market share}

To measure the position of life insurance companies operating in India, market share in terms of total premium earned by life insurers is taken as a proxy for a company's 
efficiency. Efficiency is not an absolute Figure but should always be expressed as a ratio of output by input. While treating the total premium earned by the respective life insurance companies as output of efficiency, we treat the total premium of all the 13 companies under study as inputs. Hence, Market Share is expressed as a percentage which would be obtained by multiplying the ratio with 100 and takes the following form:

$$
M_{S h_{i}}=\frac{T L I P_{i}}{\text { TLIP of all the } 13 \text { companies }}
$$

where

$T L I P_{i}=$ Total Life Insurance Premium of $\mathrm{i}^{\text {th }}$ company

$M s h_{i}=$ Market Share of $\mathrm{i}^{\text {th }}$ company

\subsection{Comparative Analysis of the Growth of Life Insurance Firms}

The thirteen companies will now be analysed on the basis of six growth indicators mentioned above through semi-log regression equations.

\subsection{New policies issued}

The overall growth rates for new policies issued for the period 2005- 2013 with semi-log equations have been estimated for life insurance companies (Table 2).

Table 2: Growth Rate of New Policies Issued (2005-2013)

\begin{tabular}{|l|c|c|c|c|}
\hline $\begin{array}{l}\text { Life Insurance } \\
\text { Companies }\end{array}$ & R Square & $\begin{array}{c}\text { Slope Coefficient } \\
\text { or Growth Rate }\end{array}$ & P-value & $\begin{array}{c}\text { Level of } \\
\text { Significance }\end{array}$ \\
\hline Aviva Life & 0.77 & 0.247 & 0.00 & $* * *$ \\
\hline Bajaj Allianz & 0.699 & 0.268 & 0.00 & $* * *$ \\
\hline Birla Sunlife & 0.743 & 0.325 & 0.005 & $* * *$ \\
\hline HDFC Standard & 0.815 & 0.150 & 0.00 & $* * *$ \\
\hline ICICI Pru & 0.434 & 0.113 & 0.075 & $* *$ \\
\hline ING Vysya & 0.885 & 0.152 & 0.00 & $* * *$ \\
\hline Kotak Mahindra & 0.689 & 0.244 & 0.010 & $* * *$ \\
\hline MaxLife & 0.829 & 0.094 & 0.00 & $* * *$ \\
\hline MetLife & 0.625 & 0.189 & 0.019 & $* * *$ \\
\hline Reliance Life & 0.765 & 0.465 & 0.00 & $* * *$ \\
\hline SBI Life & 0.612 & 0.235 & 0.021 & $* * *$ \\
\hline TATA AIA & 0.043 & -0.020 & 0.618 & $*$ \\
\hline LIC & 0.540 & 0.070 & 0.037 & $* * *$ \\
\hline
\end{tabular}

Data Source: IRDA Handbook 2012-2013

$* * *, * *$ and $*$ represent high level of significance (Less than 5\%, moderate level of significance $(5 \%-10 \%$, and low level of significance (11\%-15\%) respectively; \# represents insignificance level (above 15\%) 
The firms are compared in terms of instantaneous growth rate of new policies issued by them. The adjusted $\mathrm{R}$ square, the slope coefficient of regressand (dependent variable) which basically gives us growth rate per annum, and its p-value depicting significance level are estimated and compared.

Table 2 shows that the growth rates of life insurers in terms of new policies issued. From the Table, we can see that all the life insurers have a significant growth rate except for Tata AIA which has got a negative growth rate of $2 \%$ but it is insignificant. This analysis shows that new policies issued are on the rise for almost all the life insurers operating in India. Reliance Life Insurance Company Ltd. has got the highest growth rate of $46.5 \%$ in terms of new policies issued. This company is followed by Birla SunLife which registered a growth rate of $32.5 \%$. Bajaj Allianz (26.8\%), Aviva (24.7\%), Kotak Mahindra (24.4\%) and SBI Life (23.5\%) are next in line and are also close to each other in terms of growth rate. The company which has registered the least growth rate in terms of new policies issued is LIC.

\subsection{First year premium}

The overall growth rates for first year premium for the period 2005 up to 2013 with semi-log equations have been estimated for life insurance companies in Table 3. The life insurers are compared in terms of instantaneous growth rate of First Year Premium earned by them. The Adjusted R Square, the slope coefficient of regressand (dependent variable) which basically gives us growth rate per annum, and its P-value depicting significance level are estimated and compared.

Table 3 shows the growth rates of life insurance firms in terms of First Year Premium. From the Table, we can see that some life insurance firms have a registered a significant growth rate while some have registered insignificant growth rate. This analysis shows that although new policies issued are on the rise for almost all the life insurance firms operating in India, not all the firms have got significant growth rates in terms of first year premium earned by them. Aviva life insurance company Ltd. has got the highest growth rate of $24.7 \%$ in terms of First Year Premium. This company is followed by SBI Life which registered a growth rate of 22.8\%. Bajaj Allianz, ICICI Pru, Reliance Life and TATA AIA have registered an insignificant growth rates in terms of First Year Premium.

\subsection{Sum assured}

The growth rates for sum assured for the period starting from 2005 up to 2013 with semi-log equations have been estimated for life insurance firms in Table 4. The firms are compared in terms of instantaneous growth rate of sum assured. The adjusted $\mathrm{R}$ square, the 
slope coefficient of regressand (dependent variable) which basically gives us growth rate per annum, and its P-value depicting significance level are estimated and compared.

Table 3: Growth Rate of First Year Premium (2005-2013)

\begin{tabular}{|l|c|c|c|c|}
\hline & R Square & $\begin{array}{c}\text { Slope Coefficient } \\
\text { or Growth Rate }\end{array}$ & p-value & $\begin{array}{c}\text { Level of } \\
\text { Significance }\end{array}$ \\
\hline Aviva Life & 0.127 & 0.247 & 0.00 & $* * *$ \\
\hline Bajaj Allianz & 0.114 & -0.042 & 0.412 & $\#$ \\
\hline Birla Sunlife & 0.381 & 0.132 & 0.102 & $* *$ \\
\hline HDFC Standard & 0.865 & 0.188 & 0.00 & $* * *$ \\
\hline ICICI Pru & 0.071 & 0.040 & 0.521 & $\#$ \\
\hline ING Vysya & 0.432 & 0.082 & 0.076 & $* *$ \\
\hline Kotak Mahindra & 0.54 & 0.133 & 0.035 & $* * *$ \\
\hline MaxLife & 0.640 & 0.169 & 0.016 & $* * *$ \\
\hline MetLife & 0.505 & 0.206 & 0.048 & $*$ \\
\hline Reliance Life & 0.262 & 0.207 & 0.194 & $*$ \\
\hline SBI Life & 0.572 & 0.228 & 0.029 & $* * *$ \\
\hline TATA AIA & 0.098 & 0.051 & 0.449 & 0.010 \\
\hline LIC & 0.694 & 0.121 & & $*$ \\
\hline
\end{tabular}

Data Source: IRDA Handbook 2012-2013

$* * *, * *$ and $*$ represent high level of significance (Less than 5\%, moderate level of significance (5\%-10\%), and low level of significance (11\%-15\%) respectively; \# represents insignificance level (above 15\%)

Table 4: Growth Rates of Sum Assured (2005-2013)

\begin{tabular}{|l|c|c|c|c|}
\hline & R Square & $\begin{array}{c}\text { Slope Coefficient } \\
\text { or Growth Rate }\end{array}$ & p-value & $\begin{array}{c}\text { Level of } \\
\text { Significance }\end{array}$ \\
\hline Aviva Life & 0.947 & 0.892 & $4.73 \mathrm{E}-05$ & $* * *$ \\
\hline Bajaj Allianz & 0.736 & 0.276 & 0.00 & $* * *$ \\
\hline Birla Sun Life & 0.747 & 0.504 & 0.005 & $* * *$ \\
\hline HDFC Standard & 0.856 & 0.348 & 0.00 & $* * *$ \\
\hline ICICI Pru & 0.885 & 0.296 & 0.00 & $* * *$ \\
\hline ING Vysya & 0.898 & 0.239 & 0.00 & $* * *$ \\
\hline Kotak Mahindra & 0.747 & 0.370 & 0.00 & $* * *$ \\
\hline MaxLife & 0.863 & 0.159 & 0.000 & $* * *$ \\
\hline MetLife & 0.720 & 0.214 & 0.00 & $* * *$ \\
\hline Reliance Life & 0.867 & 0.420 & 0.000 & $* * *$ \\
\hline SBI Life & 0.847 & 0.377 & 0.001 & $* * *$ \\
\hline TATA AIA & 0.294 & 0.072 & 0.16 & $* * *$ \\
\hline LIC & 0.730 & 0.138 & 0.006 & $*$ \\
\hline
\end{tabular}

Data Source: IRDA Handbook 2012-2013

$* * *, * *$ and $*$ represent high level of significance (Less than 5\%, moderate level of significance (5\%-10\%, and low level of significance (11\%-15\%) respectively; \# represents insignificance level (above 15\%) 
Table 4 has shown growth rates of life insurers in terms of sum assured during the selected period. From the Table, we can observe that all the firms have a registered a significant growth rate except for Tata AIA which has registered an insignificant growth rate. This analysis shows that the scale of operation of almost all life insurance companies under study is on the rise and the rate of growth is also very high. As in case of First Year Premium, Aviva Life Insurance Company Ltd. has again registered the highest growth rate of $89.2 \%$ in terms of sum assured also. This company is followed by Birla SunLife, SBI Life, Kotak Mahindra, HDFC Standard and ICICI pru with the growth rates of 50.4\%, $37.7 \%, 37 \%, 34.8 \%$ and $29.6 \%$ respectively. LIC is the company which has registered the lowest growth rate of $13.8 \%$.

\subsection{Net benefit paid}

The growth rates for 'net benefit paid' for the period from 2005 to 2013 with semi$\log$ equations have been estimated for life insurance companies in Table 5. The life insurers are compared in terms of instantaneous growth rate of 'net benefit paid'. The adjusted $\mathrm{R}$ square, the slope coefficient of regressand (dependent variable) which indicates the growth rate per annum, and its p-value depicting significance level are estimated and compared.

Table 5: Growth Rate of Net Benefit Paid (2005-2013)

\begin{tabular}{|l|c|c|c|c|}
\hline & R Square & $\begin{array}{c}\text { Slope Coefficient } \\
\text { or Growth Rate }\end{array}$ & p-value & $\begin{array}{c}\text { Level of } \\
\text { Significance }\end{array}$ \\
\hline Aviva Life & 0.945 & 0.655 & $5.11 \mathrm{E}-05$ & $* * *$ \\
\hline Bajaj Allianz & 0.899 & 0.422 & 0.00 & $* * *$ \\
\hline Birla Sunlife & 0.963 & 0.568 & $1.58 \mathrm{E}-05$ & $* * *$ \\
\hline HDFC Standard & 0.924 & 0.610 & 0.00 & $* * *$ \\
\hline ICICI Pru & 0.895 & 0.563 & 0.00 & $* * *$ \\
\hline ING Vysya & 0.926 & 0.511 & 0.00 & $* * *$ \\
\hline Kotak Mahindra & 0.936 & 0.495 & $8.25 \mathrm{E}$ & $* * *$ \\
\hline MaxLife & 0.986 & 0.610 & $7.87 \mathrm{E}-07$ & $* * *$ \\
\hline MetLife & 0.991 & 0.775 & $2.26 \mathrm{E}-07$ & $* * *$ \\
\hline Reliance Life & 0.972 & 0.746 & $6.39 \mathrm{E}-06$ & $* * *$ \\
\hline SBI Life & 0.981 & 0.673 & $1.85 \mathrm{E}-06$ & $* * *$ \\
\hline TATA AIA & 0.970 & 0.537 & $8.44 \mathrm{E}-06$ & $* * *$ \\
\hline LIC & 0.931 & 0.191 & 0.00 & $* * *$ \\
\hline
\end{tabular}

Data Source: IRDA Handbook 2012-2013

***, ** and * represent high level of significance (Less than 5\%, moderate level of significance (5\%-10\%, and low level of significance (11\%-15\%) respectively; \# represents insignificance level (above 15\%) 
Table 5 has shown growth rates of life insurers in terms of 'net benefit paid'. As may be noticed from the Table, all life insurance companies have registered a significant growth rate. It can be concluded that almost all companies under study are following somewhat similar policies of disbursing net benefits to policy holders and the rate at which this net benefit is paid is also on the rise. In case of 'net benefit paid', Met Life insurance company Ltd. has registered the highest growth rate of $77.5 \%$, followed by Reliance Life, SBI Life, Aviva, Max Life and HDFC Standard with the similarly high growth rates of $74.6 \%$, $67.3 \%, 65.5 \%, 61 \%$ and $61 \%$ respectively. Again the company which has registered the lowest growth rate is LIC with $19.1 \%$.

\subsection{Total life insurance premium}

The growth rates for total life insurance premium for the period from 2005 up to 2013 with semi-log equations have been estimated for the sampled life insurance companies in table 6 and a comparison of the output is undertaken in terms of instantaneous growth rate of total life insurance premium earned by them. The adjusted $\mathrm{R}$ square, the slope coefficient of regressand (dependent variable and an indicator of growth rate per annum) and its p-value depicting significance level are estimated and compared.

Table 6: Growth Rate of Total Life Insurance Premium (2005-2013)

\begin{tabular}{|l|c|c|c|c|}
\hline & R Square & $\begin{array}{c}\text { Slope Coefficient } \\
\text { or Growth Rate }\end{array}$ & p-value & $\begin{array}{c}\text { Level of } \\
\text { Significance }\end{array}$ \\
\hline Aviva Life & 0.655 & 0.160 & 0.014 & $* * *$ \\
\hline Bajaj Allianz & 0.237 & 0.086 & 0.220 & \# \\
\hline Birla Sunlife & 0.773 & 0.211 & 0.004 & $* * *$ \\
\hline HDFC Standard & 0.917 & 0.265 & 0.000 & $* * *$ \\
\hline ICICI Pru & 0.516 & 0.141 & 0.044 & $* * *$ \\
\hline ING Vysya & 0.765 & 0.184 & 0.004 & $* * *$ \\
\hline Kotak Mahindra & 0.775 & 0.213 & 0.003 & $* * *$ \\
\hline MaxLife & 0.877 & 0.293 & 0.000 & $* * *$ \\
\hline MetLife & 0.753 & 0.336 & 0.005 & $* * *$ \\
\hline Reliance Life & 0.589 & 0.371 & 0.026 & $* * *$ \\
\hline SBI Life & 0.777 & 0.312 & 0.003 & $* * *$ \\
\hline TATA AIA & 0.697 & 0.180 & 0.009 & $* * *$ \\
\hline LIC & 0.867 & 0.109 & 0.000 & $* * *$ \\
\hline
\end{tabular}

Data Source: IRDA Handbook 2012-2013

$* * *, * *$ and $*$ represent high level of significance (Less than 5\%, moderate level of significance (5\%-10\%, and low level of significance (11\%-15\%) respectively; \# represents insignificance level (above 15\%) 
Table 6 displays the growth rates of life insurers in terms of total life insurance premium. The result indicates that all life insurers have registered a significant growth rate except for Bajaj Allianz. This analysis shows that almost all life insurance companies under study are growing in terms of total collection of life insurance premium. The highest growth rate of $37.1 \%$ is registered by Reliance Life followed by Met Life, SBI Life, and Max Life with the growth rates of $33.66 \%, 31.2 \%$, and $29.3 \%$ respectively. LIC lagged behind others in performance and has registered the lowest growth rate of $10.9 \%$.

\subsection{Market Share}

The growth rates for 'Market Share in terms of total premium' have been estimated for the period from 2005 to 2013 with semi-log equations for life insurance companies in Table 7. The companies are compared in terms of instantaneous growth rate of market share. The adjusted $\mathrm{R}$ square, the slope coefficient of regressand (dependent variable or growth rate per annum), and its p-value depicting significance level are estimated and compared for analysis.

Table 7: Growth Rates of Market Share (2005-2013)

\begin{tabular}{|l|c|c|c|c|}
\hline & R Square & $\begin{array}{c}\text { Slope Coefficient } \\
\text { or Growth Rate }\end{array}$ & p-value & $\begin{array}{c}\text { Level of } \\
\text { Significance }\end{array}$ \\
\hline Aviva Life & 0.198 & 0.030 & 0.268 & $\#$ \\
\hline Bajaj Allianz & 0.166 & -0.043 & 0.314 & $\#$ \\
\hline Birla Sunlife & 0.6155 & 0.081 & 0.021 & $* * *$ \\
\hline HDFC Standard & 0.963 & 0.135 & $1.49 \mathrm{E}-05$ & $* * *$ \\
\hline ICICI Pru & 0.020 & 0.011 & 0.735 & $\#$ \\
\hline ING Vysya & 0.579 & 0.054 & 0.028 & $* * *$ \\
\hline Kotak Mahindra & 0.65 & 0.083 & 0.015 & $* * *$ \\
\hline MaxLife & 0.906 & 0.163 & 0.000 & $* * *$ \\
\hline MetLife & 0.697 & 0.206 & 0.000 & $* * *$ \\
\hline Reliance Life & 0.390 & 0.002 & 0.097 & $* *$ \\
\hline SBI Life & 0.742 & 0.182 & 0.005 & $* * *$ \\
\hline TATA AIA & 0.368 & 0.050 & 0.110 & $* *$ \\
\hline LIC & 0.495 & -0.019 & 0.051 & \\
\hline
\end{tabular}

Data Source: IRDA Handbook 2012-2013

***, ** and * represent high level of significance (Less than 5\%, moderate level of significance (5\%-10\%), and low level of significance (11\%-15\%) respectively; \# represents insignificance level (above 15\%)

Table 7 has shown growth rates of life insurance companies in terms of market share captured by them. From the Table, we can see that some companies have registered a significant growth rate while the others have registered insignificant growth in terms of 
capturing market share. As expected, this analysis shows that all life insurance companies do not have significant rise in terms of growth rate of market share. Met Life Insurance Company Ltd. has topped the chart with the highest growth rate of $20.6 \%$, followed by SBI Life, Max Life and HDFC Standard growing at the rates of 18.2\%, 16.3\%, and 13.5\% respectively. LIC on the other hand has lost its market share showing a negative growth rate of $-1.99 \%$.

\subsection{Summary and Conclusion}

The life insurance industry has gone through a major transformation since opening up. There has been a tremendous growth of the life insurance companies in terms of their garnering first year premium, total premium, new policies issued, market share, sum assured and in terms of many other variables. In this paper, a comparative analysis is done for the companies and the results are summarised as follows:

a) In case of 'new policies issued', the growth rate p.a. of Reliance Life (46.5\%) is the highest while LIC has registered the lowest growth rate of $7 \%$ p.a.

b) In case of 'first year premium', the growth rate p.a. of Aviva life (24.7\%) is the highest while ING Vysya has registered the lowest growth rate of 8.2\%.p.a.

c) As far as 'sum assured' is concerned, Aviva Life registered the highest growth rate of $89.2 \%$ p.a. while LIC has registered the lowest growth rate of $13.8 \%$ p.a.

d) In case of 'net benefit paid', Met Life is at the top in terms of instantaneous growth rate $(77.5 \%$ p.a.) while LIC is at the bottom with a growth rate of $19.1 \%$ p.a.

e) In terms of 'total life insurance premium', Reliance Life is at the top with $37.1 \%$ growth rate p.a. while LIC is at the bottom with a growth rate of $10.9 \%$ p.a.

f) In case of 'market share', Met Life is at the top in terms of instantaneous growth rate (20.6\% p.a.) while LIC is at the bottom with a negative growth rate of $2 \%$ p.a.(approx). It implies that market share of LIC is falling at the rate of $2 \%$ p.a.

Hence, the companies are analysed in terms of certain variables for the period 2005 to 2013 and it is found that almost all the companies are growing in terms of the above considered indicators of growth and the rate of growth is different for different companies. We can now answer the question as to whether LIC has been affected by competition and liberalisation. The growth rate of market share of LIC is falling significantly. In terms of most of the other variables, LIC has been at the bottom of the list. Hence competition and liberalisation has significantly affected the position of LIC. 


\section{References}

Agarwal, U. (2014). Insurance sector in India: Growth and prospects, Ch. 2. In (Ed.) Yadav, B.S. et al. Development of Life Insurance Sector in India, Issues and Challenges. Shree Publishers and Distributors, New Delhi.

Ashturkar, P. B. (2014). Performance measurement of claims paid and unpaid: Comparative study of life insurance companies in India. International Journal of Advances Research in Management and Social Science, 3(11): 11- 21.

Bawa, S.K. \& Chattha, S. (2013). Financial performance of life insurers in Indian insurance industry. Pacific Business Review International, 6(5): 44-52.

Dhingra, T. (2016). Market micro structure of Indian life insurance industry: A general trend analysis. Pragati: Journal of Indian Economy, 3(1): 1-20.

Garg, M.C. \& Verma, A. (2010). An empirical analysis of marketing mix in the life insurance industry in India. IUP Journal of Management Research, 9(2): 7-20.

IRDA. (2012). Handbook of Statistics, 2011-2012, Retrieved from www.irda.gov.in. [Accessed: 30 November, 2013].

IRDA. (2013). Handbook of Statistics, 2012-2013, Retrieved from www.irda.gov.in. [Accessed: 20 August, 2014].

Indu \& Paliwal, R. (2014). Review study of life insurance in public and private sector. Ch.9. In (ed.) Yadav, B.S. et al. Development of Life Insurance Sector in India: Issues and Challenges. Shree Publishers and Distributors, New Delhi.

Nagaraja, B. (2014). Performance of insurance industry in India: A critical analysis. Journal of Multidisciplinary and Scientific Emerging Research, 14(1): 1045-1052.

Neelaveni, V. (2012). Financial Performance of Life Insurance Companies and Products. Zenith International Journal of Business Economic and Management Research, 2(3): 233258. 
94 | PRAGATI: Journal of Indian Economy, Volume 3, Issue 2

Sinha, R.P. (2009). Are Indian Life Insurance Companies Cost Efficient? Retrieved online from http://ssrn.com/1391904 [Accessed: 20 June, 2013].

Tanu \& Goswami, N. (2014). An Empirical Study of Insurance and its Impact on the Economic Growth. Shree Publishers and Distributors, New Delhi, India. 